Uche-Nwachi et al., Afr J Tradit Complement Altern Med. (2011) 8(1):69-78

\title{
STEROIDOGENIC ENZYME HISTOCHEMISTRY IN THE TESTIS OF SPRAGUE DAWLEY RATS FOLLOWING THE ADMINISTRATION THE WATER EXTRACTS FROM CARICA PAPAYA SEED
}

\author{
E. O. Uche-Nwachi ${ }^{1}$ C. V. Mitchell ${ }^{2}$ and C.McEwen ${ }^{3}$ \\ Anatomy Unit, Faculty of Medical Sciences, UWI, Trinidad \\ E-mail: $\underline{\text { eddydecos@yahoo.com }}$, $\underline{\text { cams29@gmail.com }}$, carolmc@ $^{\text {hotmail.com }}{ }^{3}$
}

\begin{abstract}
Water extracts from pawpaw seed have been reported to reversibly decrease the testicular weight and to suppress spermatogenesis, and fertility of Wistar rats. The reversible changes become evident, $30-45$ days after the withdrawal of the extract. The possible effect of this extract on the activities of steroidogenic enzymes of the testis has not been investigated. Water extract of papaya seeds was administered to male Sprague Dawley rats ad libitum for 84 days. Following the discontinuation of the extracts, ten rats each were sacrificed on days $0,10,20$ and 30 after the withdrawal. Their testes were quickly dissected out and frozen. Cryostat sections, $10 \mu \mathrm{m}$ thick were cut. These sections were used for immunohistochemical stains for side chain cleavage enzyme and aromatase, and for histochemical stains for 17- $\beta$ Hydroxysteroid dehydrogenase, 3- $\beta$ Hydroxysteroid dehydrogenase. We conclude that the water extract of papaya seed suppresses the activities of steroidogenic enzymes in the testis of Sprague Dawley rats, and that this may contribute to reversible suppression of spermatogenesis, a property that gives a possible male contraceptive potential.
\end{abstract}

Key words: carica papaya seed extract; steroidogenic enzyme histochemistry

\section{Introduction}

Cholesterol side-chain cleavage enzyme (P450scc, CYP11A), catalyzes the first and rate-limiting enzymatic step in the biosynthesis of all steroid hormones. The reaction requires three molecules of oxygen, three molecules of NADPH, and the mitochondrial electron transfer system (Payne and Hales, 2004). It catalyzes three sequential oxidation reactions of cholesterol with each reaction requiring one molecule of oxygen and one molecule of NADPH. The first reaction is the hydroxylation at $\mathrm{C} 22$ followed by hydroxylation at C20 to yield 20,22R-hydroxy-cholesterol that is cleaved between C22 and C20 to yield the C21 steroid pregnenolone and isocaproaldehyde. Isocaproaldehyde is then oxidized to isocaprioic acid (Boyd and Simpson, 1968, Burnstein and Gut, 1976). The electrons required for the reaction are transferred from NADPH to ferrodoxin and finally to P450scc (Simpson, 1979).

In the adrenal cortex, P450scc is expressed in all three zones, the zona glomerulosa, the zona fasciculata and the zona reticularis (Pelletier et al., 2001; Payne and Youngblood, 1995). The only site of expression in the testis is the Leydig cell (Payne and Youngblood, 1995).

In the primate placenta, the syncytiotrophoblast is the site of expression of P450scc (Strauss et al 1996) whereas, in rodent placentas, P450scc is expressed in giant trophoblast cells during midpregnancy (Arensburg et al., 1999; Ben-Zimra et al., 2002).

Aromatase (CYP19, P450arom, cytochrome P450arom, estrogen synthase), catalyzes the conversion of the C19 androgens, androstenedione and testosterone to the C18 estrogens, estrone and estradiol, respectively (Payne and Hales, 2004). The reaction involves the microsomal electron transfer system cytochrome P450 reductase and three molecules each of oxygen and NADPH (Graham-Lorence et al., 1991; Simpson et al., 1994).

The testicular expression of aromatase has been demonstrated by measuring the secretion of estradiol by human, simian, canine, and rat testis (Kelch et al., 1972; de Jong et al., 1973). Studies on separated seminiferous tubules and intact testicular tissue from human testes indicated that the major site of aromatization in human testes is in the interstitial tissue (Payne et al., 1976). Immunohistochemical studies in human testes showed that aromatase was detected in Leydig cells and absent in Sertoli cells in normal adult testes (Brodie and Inkster, 1993).

Studies investigating the testicular site of aromatization of testosterone to estradiol using rat testes or isolated testicular cells demonstrated that P450arom was expressed in Leydig cells from 25-day-old and 60 to 70-day old rats. Mammalian testis expresses aromatase activity, and produces significant amount of estradiol (Bourguiba et al., 2003). Aromatase, which converts testosterone to estradiol, could be involved in the acquisition of sperm motility, and men with congenital aromatase deficiency are sterile, suggesting that estrogens play a physiological role in the regulation of spermatogenesis in mammals (Carreau et al., 2003). Human ejaculated spermatozoa contain active P450 aromatase (Aquila et al., 2002).

Studies examining Sertoli cells from immature rat testes maintained in culture provided evidence for aromatase activity with the highest expression in Sertoli cells from 5-day-old rats with decreasing expression in age becoming essentially undetectable in rats aged 30 days and older (Dorrington and Khan, 1993). Taken together, the above-mentioned studies indicate 
there is a shift in the site of testicular somatic cell expression of CYP19 from Sertoli cells in neonatal rats to the Leydig cells of pubertal and mature rats (Kamat et al., 2002)).

The role of aromatase in male fertility has been getting more attention. It has been reported that treatment with aromatase inhibitor increased serum testosterone/estradiol ratio and increased serum testosterone levels and therefore is recommended for infertile patients with high estrogen levels (Ito et al., 1991; Shetty et al., 1997)

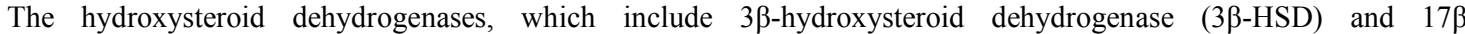
hydroxysteroid dehydrogenases (17ß-HSD), belong to the same phylogenetic protein family, as alcohol dehydrogenase /reductase family (Penning, 1997).

One of the major differences between the P450 enzymes and the hydroxysteroid dehydrogenases is that each of the P450 enzymes is a product of a single gene whereas there are several isoforms for the 3ßHSDs and several isozmyes of the $17 \beta$ HSDs, each being a product of a single gene (Payne and Hales, 2004). The number of isoforms of isozymes varies in different species, in tissue distribution, and catalytic activity. Some function predominantly as dehydrogenases or reductases. Substrate and cofactor specificity, and sub cellular localization are characteristic of these isoezymes (Payne and Hales, 2004).

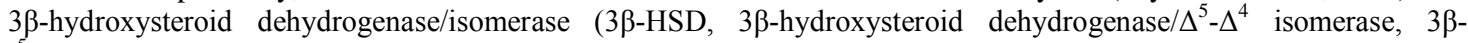
hydroxy- $\Delta^{5}$-steroid dehydrogenase, $3 \beta$-hydroxy-5-ene steroid dehydrogenase.) enzymatic action is essential for the production of all active steroid hormones. Active steroid hormones are $\Delta 4-3$-keto steroids, progesterone, testosterone, cortisol or aldosterone, or are derived from a $\Delta^{5}-3$ keto steroid (Payne and Hales, 2004).

Human $3 \beta$-HSD I and II and mouse 3 $\beta$-HSD I and IV are the sole isoforms involved in the biosynthesis of all active

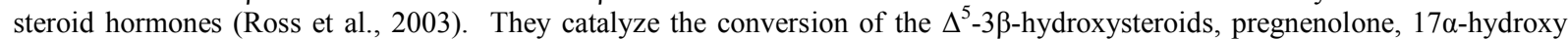
pregnenolone, and dehydroepiandrosterone (DHEA), to the $\Delta^{4}-3$-ketosteroids, progesterone, 17 $\alpha$-hydroxyprogesterone, and androstenedione respectively (Thomas et al., 1989; Thomas et al., 1995; Thomas et al., 2003).

The isoforms of 3 $\beta$-HSD are expressed in a cell and tissue-specific manner. It has been demonstrated that human $3 \beta-$ HSD I is expressed in the placenta, skin, and breast tissue whereas $3 \beta$-HSD II is expressed in the adrenal gland, ovary and testis

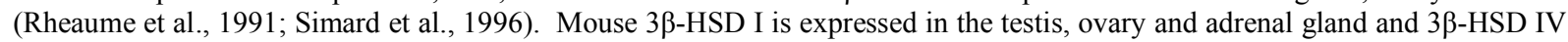
is observed in the placenta, skin and testis (Abbaszade et al., 1997).

In situ hybridization in mouse testicular sections demonstrated the exclusive expression of $3 \beta-\mathrm{HSD}$ in the Leydig cells of the

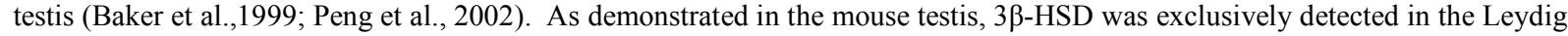
cell. Studies have demonstrated that immunostaining for $3 \beta$-HSD was found exclusively in the mitochondria of the Leydig cell (Pelletier et al., 2001).

$17 \beta$-hydroxysteroid dehydrogenase (17 $\beta$-HSDs) plays essential roles in steroidogenesis. These enzymes catalyze the final step in the biosynthesis of active gonadal steroid hormones, estradiol and testosterone, and unlike other steroidogenic enzymes, 17ß-HSD is not involved in the biosynthesis of adrenal steroids (Payne and Hales, 2004).

The $17 \beta$-HSDs convert inactive 17-ketosteroids into their active $17 \beta$-hydroxy form. The $17 \beta$-HSDs are found as either membrane-bound or soluble enzymes (Payne and Hales, 2004). Eleven different 17 $\beta$-HSDs have been identified.

The $17 \beta$-HSDs differ in tissue distribution, catalytic preferences, substrate specificity, subcellular localization, and mechanisms of regulation. Among the many different forms of $17 \beta$-HSDs, three forms participate in the final step of biosynthesis of active steroid hormones in gonads, types I; III, and VII (Payne and Hales, 2004).

$17 \beta$-HSDI was the first to be cloned and characterized. It was first purified from human placenta (Payne and Hales, 2004) and was subsequently found to be expressed in the ovary and mammary gland (Luu-The, 2001). Human 17ß-HSD I has substrate specificity for estrogens whereas the rodent enzyme can utilize both estrogens and androgens (Penning, 1997; Peltketo

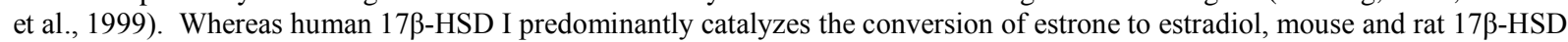
I also efficiently convert androstenedione to testosterone (Puranen et al 1997). The expression of 17ß-HSD I exhibits speciesspecific differences which may be due to different mechanisms; that control cell-and tissue-specific regulation. In the ovary, 17ß-HSD I is primarily induced by Follicle Stimulating Hormone (FSH) acting via the cAMP-dependent protein kinase (PKA) pathway (Peltoketo et al., 1999).

$17 \beta$-HSD III converts androstenedione, a weak androgen, to testosterone, a potent one. 17ß-HSD III prefers NADPH as a cofactor and its primary activity is reductive. It is exclusively expressed in the testes (Geissler et al., 1995; Andersson, 1995a,1995b). Its expression is restricted to the adult Leydig cell population and this serves a specific marker for Leydig cell development (O'Shaughnessy et al., 2000).

The major biochemical pathways of steroid hormone synthesis in the gonads are illustrated in the diagram below. Both genders use the same pathway of steroid hormone biosynthesis in gonadal tissue.

In the male, cholesterol is absolutely necessary for androgen biosynthesis. It can either be synthesized within the cell from acetate or it can be taken up in association with high-density lipoproteins (HDL) via HDL receptors in the cell surface membrane (Brown and Goldstein, 1998). When androgen biosynthesis is not taking place, cholesterol is esterified and stored in microscopic lipid droplets (Morris, 1996). During androgen biosynthesis, leutinizing hormone (LH) stimulates the hydrolysis of esterified cholesterol to produce free cholesterol, which is then transported to the mitochondria via sterol carrier-protein (SCP-2) [Stocco and Clarke, 19994] and steroidogenic acute regulatory protein (STAR) (Clark et al., 1994). 
Uche-Nwachi et al., Afr J Tradit Complement Altern Med. (2011) 8(1):69-78

\section{CHOLESTEROL}

$\downarrow$ P450scc

PREGNENOLONE------------------- $\rightarrow 17 \alpha-H Y D R O X Y P R E G N E N O L O N E----------------\quad \rightarrow$ DHEA

$\downarrow 3 \beta-H S D \quad \downarrow 3 \beta-H S D \quad \downarrow 3 \beta-H S D$

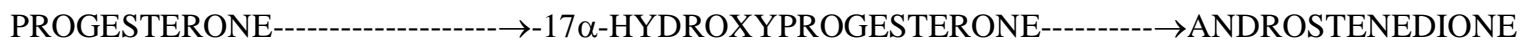

\section{7ק-HSD $\downarrow$ \\ TESTOSTERONE \\ $\downarrow P 450$ arom \\ ESTRONE}

P450 arom $\downarrow$ $\downarrow 17 \beta-H S D$

\section{ESTRADIOL}

Androgen synthesis begins when cholesterol is carried to the inner mitochondrial membrane within the Leydig cells by SCP-2 and STAR where cholesterol side chain cleavage (P450scc) is located (Morris, 1996). The delivery of cholesterol to the inner mitochondrial membrane is believed to be the rate-limiting step in steroidogenesis, unless cholesterol is in excess; in that case, the conversion of cholesterol to pregnenolone becomes the limiting step (Stocco and Clarke, 1994).

The $\Delta^{4}$ steroidogenic pathway (pregnenolone-progesterone-androstenedione-testosterone) is the major route of androgen syntheis in the rat testis (Stocco and Clarke, 19994). Pregnenolone can also be converted to dehydroepiandrosterone (DHEA) by P45c17. The reaction sequence (pregnenolone-DHEA-androstenedione-testosterone) is the $\Delta^{5}$ pathway. Both the $\Delta^{4}$ and $\Delta^{5}$ pathways of androgen synthesis operate in the human testis (Morris, 1996).

Carica papaya seed extract may selectively act on the developing germ cells, possibly through Sertoli cells, leading to azoospermia, and the inhibitory effect of benzene chromatographic fraction of the chloroform extract could be due to its effect on sperm motility (Lohiya et al., 2002; Manivannan et al., 2004). Sperm motility is inhibited by benzene chromatographic fraction of the chloroform extract of Carica papaya seed in langur monkey (Lohiya, et al., 2008). The suppression of spermatogenesis by water extract of papaya seed has been reported. It was suggested that this is possibly mediated through the loss of cell processes by Sertoli cells (Uche-Nwachi et al., 2001).

The aim of this investigation is to determine the effects of water extracts of papaya seed on the steroidogenic enzymes in the testis. This will enable us determine whether the reversible suppression of spermatogenesis reported by this extract is mediated through these enzymes.

\section{Material and Methods \\ Preparation of the water extract}

Carica papaya seeds were obtained from locally purchased ripe fruits. The seeds were dried in the oven at $34^{0} \mathrm{C}$. The dried seeds were ground into fine powder. One hundred grams of the ground powder was soaked in $250 \mathrm{ml}$ of distilled water for $24 \mathrm{hrs}$ at room temperature. The mixture was stirred vigorously before filtration. The filtrate was used for the experiment.

\section{Animals}

Fifty male Sprague Dawley rats, aged 3 months and above and weighing 250-350 grams were used for this investigation. They were caged in groups of five rats. The rats were left in their cages for 24 hrs to acclimatize before the experiment commenced. The rats in cages 1 and 2 were the control, while those in cages 3-12 were the experimental animals. All the animals were given food ad libitum during the experiment. The care of the animals was strictly in accordance with the guidelines of the Animal House Committee of the Faculty of Medical Sciences, University of the West Indies. Control rats were given normal food and water ad libitum during the experiment. Rats in cages 3-12 were given the water extract of papaya seed in place of water ad libitum for 84 days. At the end of the $84^{\text {th }}$ day, the water extract was discontinued. Ten rats form the control 
and ten rats from each the experimental groups were sacrificed, following diethyl ether anesthesia. Another set of ten rats were sacrificed on the $10^{\text {th }}$ day following the discontinuation of the extract, while another set of ten rats were sacrificed of the $20^{\text {th }}$ day, and the last set of ten rats were sacrificed on the $30^{\text {th }}$ day following the discontinuation of the extract. Their testes were quickly dissected out and frozen. Cryostat sections $10 \mu \mathrm{m}$ thick were cut from the rats testes (control and experimental groups), for histochemical and immunohistochemical stains.

Histochemical Methods

3-Beta Hydroxysteroid Dehydrogenase (3ß-HSD)

The histochemistry of 3 $\beta$-HSD was carried out using the PVA method (Stoward Pearson (ed), 1980).

\section{Preparation of Incubation Medium}

A 22\% PVA solution was prepared by adding $22 \mathrm{~g}$ of PVA to $100 \mathrm{ml}$ of $100 \mathrm{mM}$ phosphate buffer, (pH 7.4). To this was added, dehydroepiandrosterone (dissolved in 5\% dimethylformamide) and NAD. After the additions, the medium was thoroughly mixed. Finally, for each ml of the medium, $4 \mathrm{mg}$ of Nitro BT in a mixture of $20 \mu \mathrm{l}$ of N, N dimethylformamide and $20 \mu 1$ of absolute ethanol was added.

\section{Staining Method:}

Cryostat sections, $10 \mu \mathrm{m}$ thick were incubated in the complete reaction medium for 60 minutes at $37^{\circ} \mathrm{C}$. Following this, the slides were placed in Coplin jars with distilled water until the medium dissolved. The slides were left to air-dry and were then mounted in Protex. The presence of $3 \beta$-HSD was shown by the characteristic blue formazan at the reaction sites.

\section{Beta Hydroxysteroid Dehydrogenase (17 $\beta$-HSD)}

The histochemistry of 17 $\beta$-HSD was carried out using the PVA method (Stoward Pearson (ed), 1980).

\section{Preparation of incubation medium}

A $22 \%$ PVA solution was prepared by adding $22 \mathrm{~g}$ of PVA to $100 \mathrm{ml}$ of $100 \mathrm{mM}$ phosphate buffer, (pH 7.4). Androstenedione was dissolved in 5\% dimethylformamide) was added to $22 \%$ PVA and NAD. After the additions, the medium was thoroughly mixed. Finally, for each $\mathrm{ml}$ of the medium, $4 \mathrm{mg}$ of Nitro BT in a mixture of $20 \mu \mathrm{l}$ of N, N dimethylformamide and $20 \mu \mathrm{l}$ of absolute ethanol was added.

\section{Staining Method}

Sections, $10 \mu \mathrm{m}$ thick were cut using the cryostat and were incubated in the complete reaction medium for 60 mins at $37^{\circ} \mathrm{C}$. Following this, the slides were placed in Coplin jars with distilled water until the medium dissolved. The slides were left to air-dry and were then mounted in Protex. The presence of $17 \beta$-HSD was shown by the characteristic blue formazan at the reaction sites.

\section{Immunohistochemical Methods Cytochrome P450 Side Chain Cleavage Enzyme (P450sce)}

Cryostat frozen sections of the testis, $10 \mu \mathrm{m}$ thick were pre-incubated in 5\% non-fat milk in Phosphate Buffer Saline (PBS) for 30 mins at room temperature. The sections were then incubated overnight in a humidified chamber with the primary antibody rabbit $\mathrm{P} 450 \mathrm{scc}$ at $25^{\circ} \mathrm{C}$. They were then rinsed in $\mathrm{Tris} \mathrm{NaCl}(\mathrm{pH}$ 7.4) following which they were incubated with secondary antibody, (goat biotinylated anti-rabbit antibody) diluted in Tris-NaCl buffer for one hour. After rinsing with Tris/ $\mathrm{NaCl}$ buffer ( $\mathrm{pH} 7.4$ ), Avidin Biotin Complex (ABC) was applied at a concentration of $10 \mu 1$ of Avidin (A) and $10 \mu 1$ of B (B) per $\mathrm{ml}$ of Tris $/ \mathrm{NaCl}$ for one hour. The sections were then rinsed in Tris/ $\mathrm{NaCl}$ and placed in sodium acetate buffer $0.1 \mathrm{M}, \mathrm{pH} 6.0$ while the following staining solution was prepared: 1.5 grams Ammonium Nickel Sulphate was dissolved in $50 \mathrm{ml}$ of sodium acetate buffer $0.2 \mathrm{M}$ ( $\mathrm{pH}$ 6.0). This was left to stir while the following were weighed out: i. $200 \mathrm{mg}$ Glucose, ii. $40 \mathrm{mg}$ Ammonium chloride, iii. $1 \mathrm{mg} \mathrm{B} \mathrm{Glucose} \mathrm{Oxidase} \mathrm{Diaminobenzidine}(50 \mathrm{mg})$ was then dissolved in $50 \mathrm{ml}$ distilled water, poured into the ammonium nickel sulphate solution and then the other salts were added in the above order in which they were measured. This solution was stirred briefly and the slides were then incubated in it for $10-15$ mins. The sections were then rinsed, dehydrated, air-dried, mounted and coverslipped in Protex. The site of the cells (inner mitochondrial membrane of Leydig cells in the testis) where P450scc is located stained purple.

\section{Aromatase (P450arom)}

The above-mentioned protocol was utilized to identify the presence of Aromatase. In this instance, the primary 
Uche-Nwachi et al., Afr J Tradit Complement Altern Med. (2011) 8(1):69-78

antibody utilized was rabbit polyclonal anti-aromatase while the secondary antibody was biotinylated anti-rabbit antibody. The egions that were stained dark purple showed the presence of aromatase enzyme.

\section{Quantification of the stains}

The stains (histochemical and immunohistochemical) were quantified using the Image J program (Rashband, 2004). (NIMH). Image $\mathrm{J}$ is a public domain image processing and analysis program for the Macintosh. It was developed at the Research Services Branch of the National Institute of Mental Health (NIMH), part of the National Institutes of Health (Rasband, 2004; Abramoff et al., 2004). The statistical analysis was done using One Way Anova (Minitab 15). Using the Image J software the staining intensity of the different histochemical stains was computed. At 8 bits pixel, the grey images of the stains were quantified. At a range of zero to 255 the histograms of the stains were plotted. Zero indicated maximum intensity while 255 indicated no stain. Ten mean values were recorded for each group and the mean staining intensities were calculated. A One-way ANOVA statistical analysis was carried out to determine the statistical significance between the mean values of the control and experimental groups. At a confidence interval (CI) of $95 \%$ a, p value of 0.05 was used to determine the statistical significance of the experimental groups when compared with the control. A representative photomicrograph, their grey images and histograms were recorded from each group.

\section{Results}

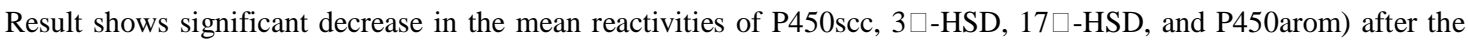
animals have been treated with the extract for 84 days $\{p<0.05\}$, (Table1-4). This decrease in the activities of these enzymes, tend to stay at this level till the 30th day following the withdrawal of the extract (Tables 1-4).

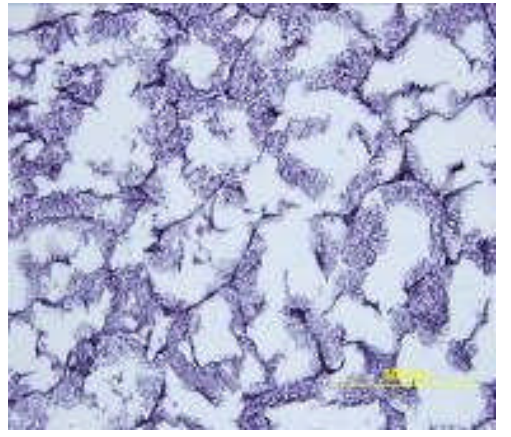

MICROGRAPH P450scc (CONTROL)

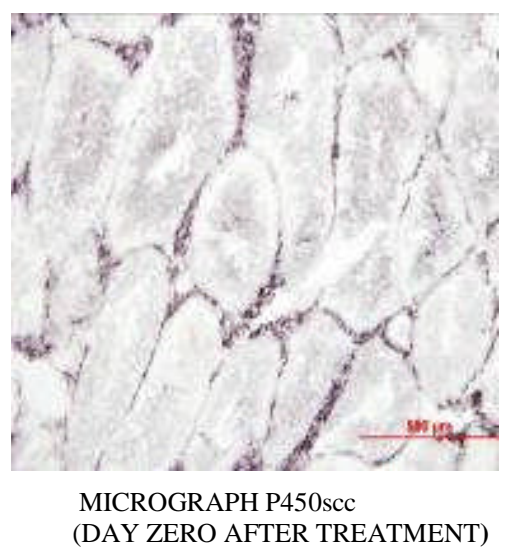

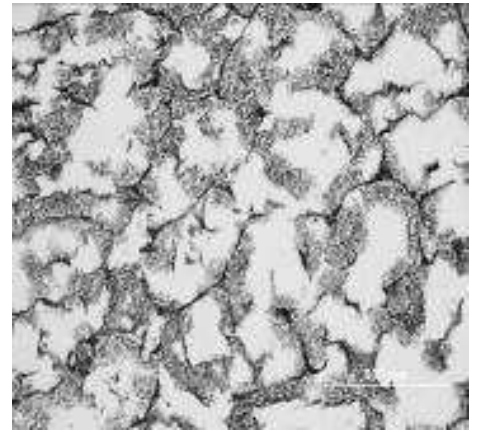

8 BITS PIXEL GREY IMAGE

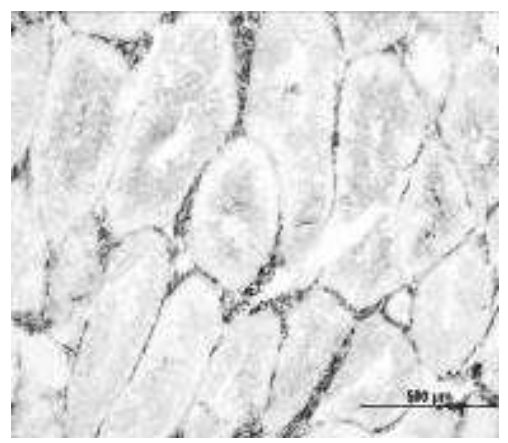

8 BITS PIXEL GREY IMAGE

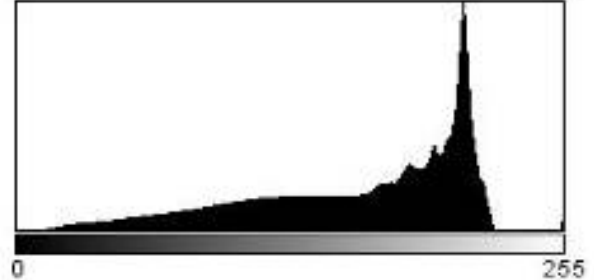

$\begin{array}{ll}\text { Count } 12533760 & \text { Min: } 2 \\ \text { Mean: } 159.65 & \text { Max. } 255\end{array}$

$\begin{array}{ll}\text { Mean: } 159.65 & \text { Max. } 255 \\ \text { StdDev: } 51.34 & \text { Mode: } 209 \text { (358248) }\end{array}$

HISTOGRAM OF GREY IMAGE

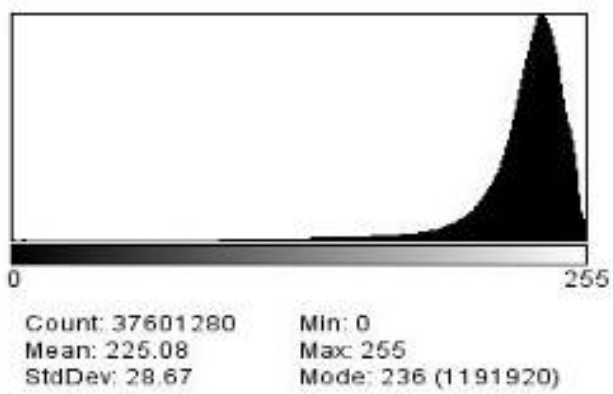

HISTOGRAM OF GREY IMAGE

Figure 1a: Representative Image J quantifications of micrographs of P450scc micrograph (control and day zero) 
Table 1: Mean pixel values for Side chain cleavage enzyme (P450scc)

\begin{tabular}{|l|l|l|l|l|l|}
\hline Rat & Control & Treatment & $\begin{array}{l}10 \text { days post } \\
\text { treatment }\end{array}$ & $\begin{array}{l}20 \text { days post } \\
\text { treatment }\end{array}$ & $\begin{array}{l}30 \text { days post } \\
\text { treatment }\end{array}$ \\
\hline Mean & $170.30 \pm 30$ & $212.78 \pm 9.60$ & $202 \pm 97 \pm 10.13$ & $215.61 \pm 3.41$ & $218.48 \pm 2.78$ \\
\hline
\end{tabular}

$\mathrm{P}<0.05$

Table 2: Mean pixel values for Aromatase enzyme (P450arom)

\begin{tabular}{|l|l|l|l|l|l|}
\hline & Control & Treatment & $\begin{array}{l}10 \text { days post } \\
\text { treatment }\end{array}$ & $\begin{array}{l}20 \text { days post } \\
\text { treatment }\end{array}$ & $\begin{array}{l}30 \quad \text { days } \\
\text { treatment }\end{array}$ \\
\hline post & & & & \\
Mean & $176.89 \pm 11.26$ & $223.78 \pm 11.08$ & $229.86 \pm 7.13$ & $228.56 \pm 2.16$ & $231.54 \pm 2.87$ \\
\hline
\end{tabular}

$\mathrm{P}<0.05$

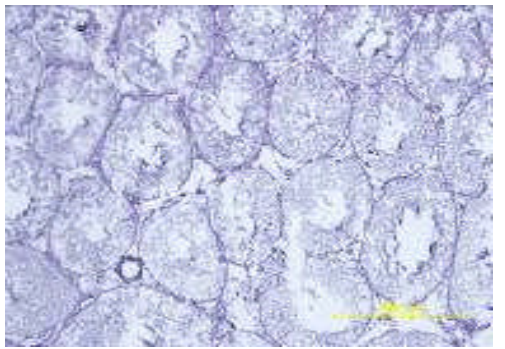

MICROGRAPH OF AROMATASE (CONTROL)

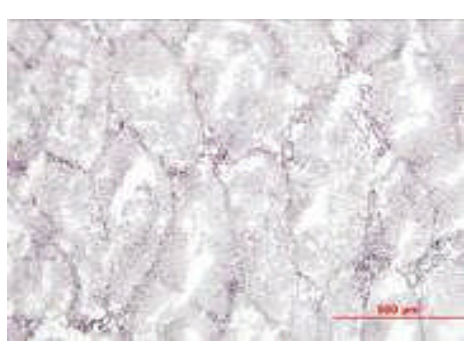

MICROGRAPH OF AROMATASE (DAY ZERO AFTER TREATMENT)

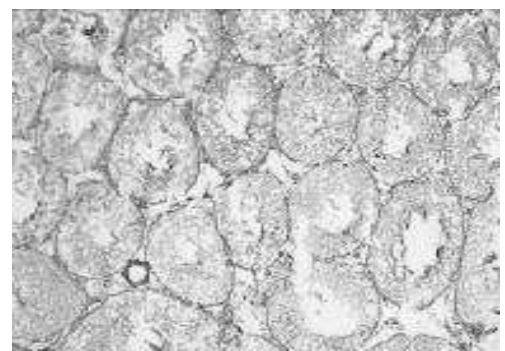

8 BITS PIXEL GREY IMAGE

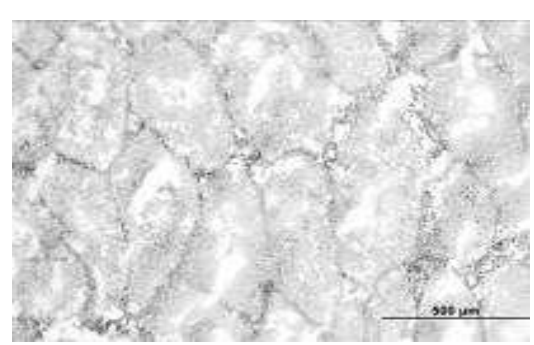

8 BITS PIXEL GREY IMAGE

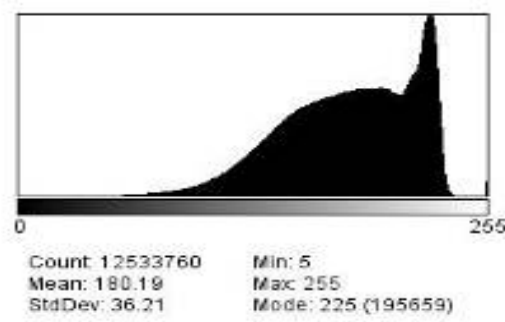

HISTOGRAM OF GREY IMAGE

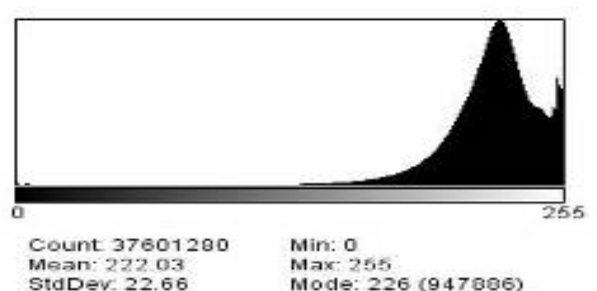

HISTOGRAM OF GREY IMAGE

Figure 2a: Representative Image J quatifications of the micrographs from aromatase (control and day zero)

Table 3: Mean pixel values for 3 Beta Hydroxysteroid Dehydrogenase (3 $\beta$-HSD)

\begin{tabular}{|l|l|l|l|l|l|}
\hline Rat & Control & Treatment & $\begin{array}{l}10 \text { days post } \\
\text { treatment }\end{array}$ & $\begin{array}{l}20 \text { days post } \\
\text { treatment }\end{array}$ & $\begin{array}{l}30 \text { days post } \\
\text { treatment }\end{array}$ \\
\hline Mean & $183.43 \pm 15.05$ & $235.03 \pm 1.56$ & $235.55 \pm 1.46$ & $235.04 \pm 2.07$ & $234.48 \pm 0.97$ \\
\hline
\end{tabular}

$\mathrm{P}<0.05$ 


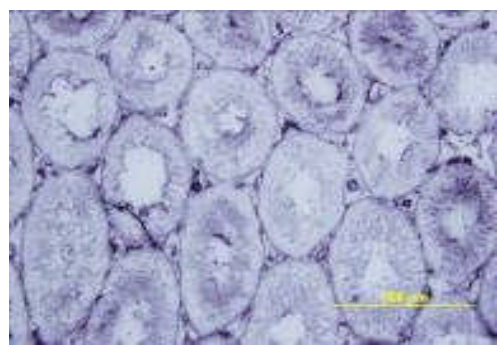

33-HSD MICROGRAPH (CONTROL)

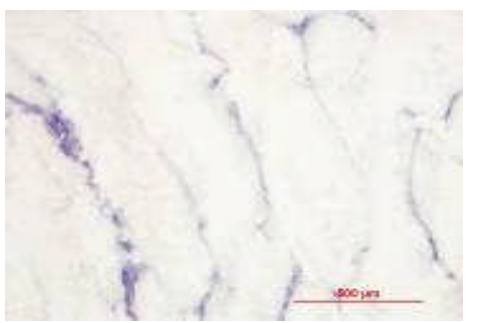

33-HSD MICROGRAPH

(DAY ZERO AFTER TREATMENT)

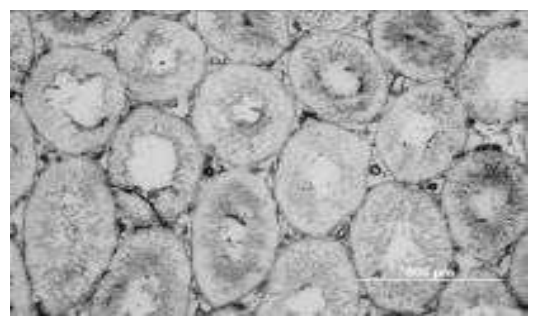

8 BITS PIXEL GREY IMAGE

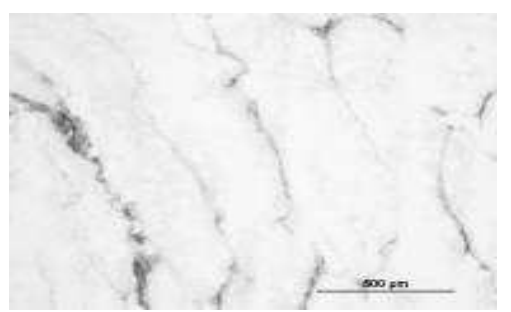

8 BITS PIXEL GREY IMAGE

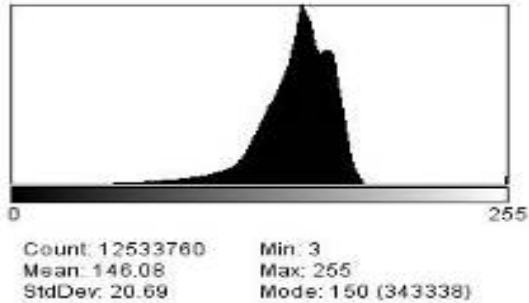

HISTOGRAM OF GREY IMAGE

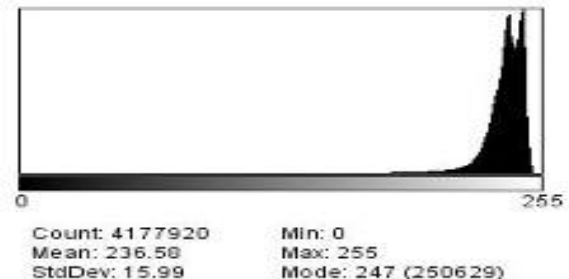

HISTOGRAM OF GREY IMAGE

Figure 3a: Representative Image J quantifications of 3ß-HSD stains (control and day zero).

Table 4: Mean pixel values for $17 \beta$-Hydroxysteroid dehydrogenase enzyme (17ß-HSD)

\begin{tabular}{|l|l|l|l|l|l|}
\hline Rat & Control & Treatment & $\begin{array}{l}10 \quad \text { days post } \\
\text { treatment }\end{array}$ & $\begin{array}{l}\text { 20 days post } \\
\text { treatment }\end{array}$ & $\begin{array}{l}\text { 30 days post } \\
\text { treatment }\end{array}$ \\
\hline Mean & $140.53 \pm 3.69$ & $233.95 \pm 4.70$ & $236.48 \pm 0.97$ & $237.32 \pm 1.32$ & $235.53 \pm$ \\
\hline
\end{tabular}

$\mathrm{P}<0.05$

\section{Discussion}

Various extracts of papaya seed have been reported to reversibly affect spermatozoa, ranging from impaired motility to decreased count (Manivannan et al ., 2004; Lohiya et al., 2008; Uche-Nwachi et al., 2001). Spermatogenesis is dependent on follicle stimulating hormone (FSH) from the pituitary and testosterone and estradiol form the testis. Any reversible suppression of spermatogenesis will inevitably involve reversible suppression of the synthesis of testosterone and estradiol.

Gonadal steroidogenesis is dependent on important enzymes that take part in this synthesis. One of the most important enzymes needed for steroidogenesis is cholesterol side chain cleavage enzyme (P450scc). This rate-determining enzyme in steroidogenesis was found in this investigation to be significantly suppressed following the treatment with the water extract for 84 days $(<0.05)$. It was also shown that this suppression stayed at the post treatment level for about 30 days after the withdrawal of the treatment ((Table 1; Figure 1a).

It was also found in this investigation that, the enzyme which switches steroidogenesis form the $\Delta^{5}$ to $\Delta^{4}$ pathway, $3 \beta$ HSD, and the enzyme which plays a final role in testosterone and estradiol synthesis were significantly suppressed following the treatment with the water extract of papaya seed (Tables 2 and 3; Figures 2a; 3a). The $\Delta^{4}$ pathway, is the major pathway used by males. 


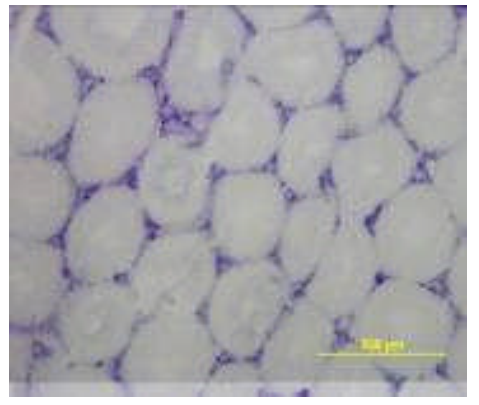

17ß-HSD MICROGRAPH (CONTROL)

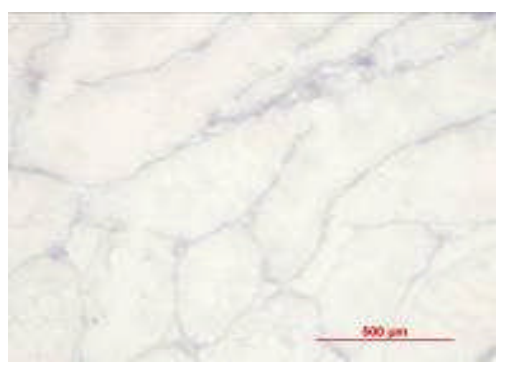

17ß-HSD MICROGRAPH

(DAY ZERO AFTER TREATMENT)

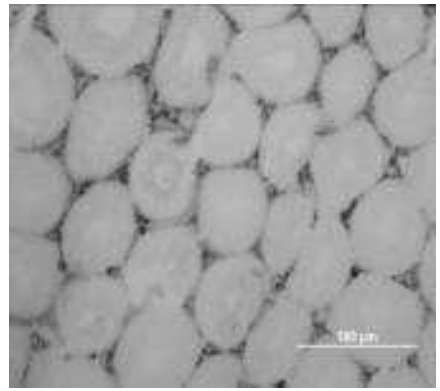

8 BITS PIXEL GREY IMAGE

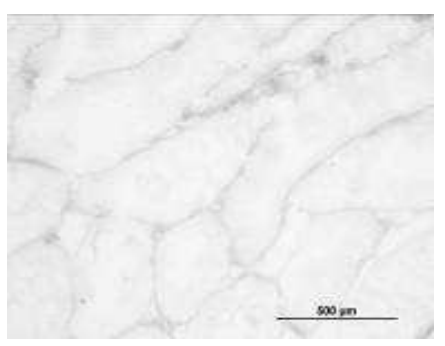

8 BITS PIXEL GREY IMAGE

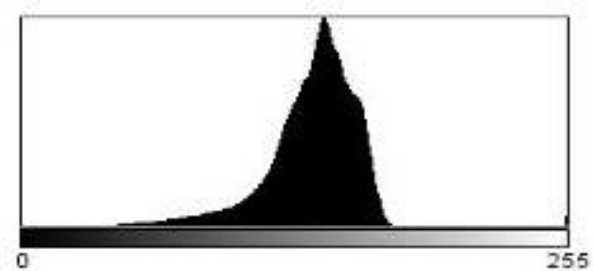

Count $12533760 \quad$ Min: 10 Mean: $135.87 \quad$ Max 255 StdDev. $21.47 \quad$ Mode: 141 (329018)

\section{HISTOGRAM OF GREY IMAGE}

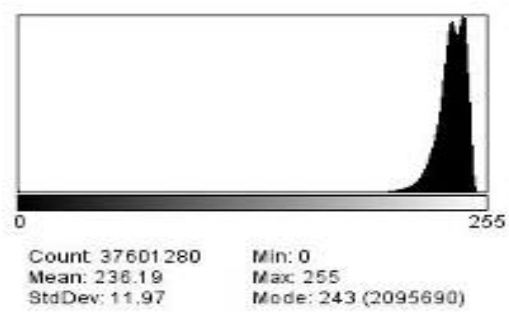

HISTOGRAM OF GREY IMAGE

Figure 4a: Representative Image J quantifications of 17 $\beta$-HSD stains (control and day zero)

The principal enzyme needed for estradiol synthesis is aromatase, whose activity was found to be significantly suppressed in this investigation, following treatment with the extract (Table 4). It was also found that the recovery rate of this suppression was slow, as the activity did not change significantly from the post treatment level 30 days after withdrawal of the extract. In this investigation we have demonstrated that the essential enzymes needed for testicular steroidogenesis were significantly suppressed, following the administration of water extract of papaya seed extract.

We conclude that the reversible suppression of spermatogenesis following oral administration of the water extract of carica papaya seed is mediated through the suppression of the enzymes essential for the synthesis of testosterone and estradiol, which are required for the production of viable number of spermatozoa for needed male fertility. This makes this extract a potential male contraceptive material.

\section{References}

1. Abbaszade I.G, Arensburg J.., Park C.H, Kasa-Vubu J.Z, Orly J., Payne A.H. (1997). Isolation of a new mouse 3ßhydroxysteroid dehydrogenase isoform, 3ß-HSD VI, expressed during early pregnancy. Endocrinology, 138:13921399.

2. Andersson S. (1995a ). Molecular genetics of androgenic 17 B-hydroxysteroid dehydrogenases. J Steroid Biochem Mol Biol.55:533-534.

3. Andersson S. (1995b).17 ß-Hydroxysteroid dehydrogenase: isozymes and mutations. J. Endocrinol. 146:197-200.

4. Aquila S., Diego S., Gentile M., Middea E., Siciliano L., and Ando S. (2002). "Human Ejaculated Spermatozoa Contain Active P450 Aromatase". The J Clinical Endocrinol. Metabolism .87: (7) 3385-3390.

5. Arensburg J., Payne A.H., Orly J. (1999). Expression of steroidogenic genes in maternal and extraembryonic cells during early pregnancy in mice. Endocrinology 140:5220-32.

6. Baker P.J, Sha J.A, McBride M.W., Peng L., Payne A.H., O'Shaughnessy P.J (1999).Expression of 3ß-hydroxysteroid dehydrogenase type I and type VI isoforms in the mouse testis during development. Eur J Biochem 260:911-917. 
7. Ben-Zimra M., Koler M., Orly J. (2002). Transcription of cholesterol side-chain cleavage cytochrome P450 in the placenta: activating protein-2 assumes the role of steroidogenic factor-1 by binding to overlapping promoter element. Mol Endocrinol 16:1864-80

8. Brodie A., Inkster S. (1993). Aromatase in the human testis. J Steroid Biochem Mol Biol., 44:549-55.

9. Bourguiba S., Genissel C., Lambard S., Bouraima H , Carreau S (2003). "Regulation of aromatase gene expression in Leydig cells and germ cells". J. Steroid Biochem Molecular Biology 86: 335-343.

10. Boyd G.S., Simpson E.R. (1968). Studies on the conversion of cholesterol to pregnenolone in bovine adrenal mitochondria, Appleton-Century Crofts, New York

11. Brown MS, Goldstein JL. (1998). A receptor-mediated pathway for glucose homeostasis. Science, 232:34-47.

12. Burnstein S., Gut M. (1976). Intermediates in the conversion of cholesterol to pregnenolone: kinetics and mechanism. Steroids, 28:115-31.

13. Carreau S., Lambard S., Delalande C., Denis-Galeraud I., Balinska B., Bourguiba S. (2003). "Aromatase expression and role of estrogens in male gonad: a review". Reproductive Biology and Endocrinology 1:35

14. Clark B.J., Wells J., King S.R., Stocco D.M. (1994). The purification, cloning and expression of a novel leutinizing hormone-induced mitochondrial protein in MA-10 mouse Leydig tumour cells. Characterization of the steroidogenic acute regulatory protein (StAR). J Biol Chem., 267:28314-28322.

15. de Jong F.H., Hey A.H., van der Molen H.J. (1973). Effect of gonadotropins on the secretion of oestradiol-and testosterone by the rat testis. J Endocrinol., 57:277-84.

16. Dorrington JH, Khan SA. (1993). Steroid Production, Metabolism and Release by Sertoli Cells. Cache River Press, Clearwater.

17. Geissler W.M., Davis D.L., Wu L., Bradshaw K.D., Patel S., Mendonca B.B., Elliston K.O., Wilson J.D., Russell D.W., Andersson S. (1995). Male pseudohermaphroditism caused by mutations of testicular 17 ß-hydroxysteroid dehydrogenase 3. Nat Genet., 7:34-39.

18. Graham-Lorence S., Khalil M.W., Lorence M.C., Mendelson C.R., Simpson E.R. (1991). Structure-function relationships of human aromatase cytochrome P-450 using molecular modeling and site-directed mutagenesis. J Biol Chem., 266:11939-46.

19. Ito N., Kumamoto Y., Maruta H., Tsukamoto T., Takagi Y., Mikuma N., Nanbu A., Tachiki H.(1991). Therapeutic efficacy of testolactone (aromatase inhibitor: to oligozoospermia with high estradiol/testosterone ratio. Nippon Hinyokika Gakkai Zasshi, 82(2): 204-9.

20. Kamat A., Hinshelwood M.M., Murry B.A., Mendelson C.R.. (2002). Mechanisms in tissue-specific regulation of estrogen biosynthesis in humans. Trends Endocrinol Metab., 13:122-128.

21. Kelch R.P, Jenner M.R, Weinstein R., Kaplan S.I., Grumbach M.M.. (1972). Estradiol and testosterone secretion by human, simian, and canine testes, in males with hypogonadism and in male pseudohermaphrodites with the feminizing testes syndrome. J Clin Invest.,51:824-30.

22. Lohiya N.K., Mannivanan B., Mishra P.K., Pathak N., Sriram S., Bhande S.S., Panneerdoss S (2002). "Chloroform extract of Carica papaya seeds induces long-term reversible azoospermia in langur monkey". Asian J Androl 4:17-26

23. Lohiya N.K., Manivannan B., Goyal S. and Ansari A.S. (2008). "Sperm motility inhibitory effect of the benzene chromatographic fraction of the chloroform extract of the seeds of carica papaya in langur monkey, Presbytis entellus entellus". Asian J Androl 10(2): 298-306.

24. Luu-The V. (2001). Analysis and characteristics of multiple types of human 17ß-hydroxysteroid dehydrogenase. J Steroid Biochem Mol Biol.,76:143-151.

25. Mannivanan B., Mishra P.K., Pathak N., Sriram S., Bhande S.S., Panneerdoss S.S., and Lohiya N.K.(2004). "Ultrastructural changes in the testis and epididymis of rats following treatment with the benzene chromatographic fraction of the chloroform extract of the seeds of Carica papaya". Phytother Res., 18(4):285-289

26. Morris I.D. (1996). The testis: Endocrine Function. In Hillier SG, Kitchener HC, Neilson JP, editors. Scientific Essentials of Reproductive Medicine. Philadelphia: Saunders, 164.

27. O'Shaughnessy P.J., Baker P.J., Heikkila M., Vainio S., McMahon A.P. (2000). Localization of 17ß-hydroxysteroid dehydrogenase/17-ketosteroid reductase isoform expression in the developing mouse testis: androstenedione is the major androgen secreted by fetal/neonatal Leydig cells. Endocrinol.,141:2631-2637

28. Payne A.H , Hales D.B. (2004). Overview of Steroidogenic Enzymes in the Pathway from Cholesterol to Active Steroid Hormones. Endocrine Reviews. Published September 8, 2004 as doi: 10. 1210/er. p.12.

29. Payne A.H., Kelch R.P., Musich S.S., Halpern M.E. (1976). Intratesticular site of aromatization in the human. J Clin Endocrinol Metab, 42:1081-1087. Not cited in the text?? ( Introduction page 1 line 22).

30. Payne A.H., Youngblood G.L. (1995). Regulation of expression of steroidogenic enzymes in Leydig cells. Boil Reprod 52: 217-25.

31. Payne A.H , Hales D.B. (2004). Overview of Steroidogenic Enzymes in the Pathway from Cholesterol to Active Steroid Hormones. Endocrine Reviews. Published September 8, 2004 as doi: 10. 1210/er. p.6.duplicated??

32. Pelletier G., Li S., Luu-The V., Trmblay Y., Belanger A., Labrie F (2001). Immunoelectromicroscopic localization of three key steroidogenic enzymes cytochrome P450(scc), 3 $\beta$-hydroxysteroid dehydrogenase, and cytochrome P450 (c 17) in rat adrenal cortex and gonads. J Endocrinol 171:373-383.

33. Peng L., Arensburg J., Orly J., Payne A.H. (2002). The murine 3ß-hydroxysteroid dehydrogenase (3ß-HSD) gene family: a postulated role for 3ß-HSD VI during early pregnancy. Mol Cell Endocrinol 187:213-221. 
34. Penning T.M. (1997). Molecular endocrinology of hydroxysteroid dehydrogenases. Endocr Rev. 18:281-305.

35. Peltoketo H., Luu-The V., Simard J., Adamski J. (1999). 17ß-hydroxysteroid dehydrogenase (HSD)/17-ketosteroid reductase (KSR) family; nomenclature and main characteristics of the 17HSD/KSR enzymes. J Mol Endocrinol., 23:111.

36. Puranen T., Poutanen M., Ghosh D., Vihko R., Vihko P (1997). Origin of substrate specificity of human and rat 17ßhydroxysteroid dehydrogenase type 1, using chimeric enzymes and site-directed substitutions. Endocrinology 138:3532-3539.

37. Rasband, W.S (1997-2004) ImageJ. National Institutes of Health, Bethesda, Maryland, USA, http://rsb.info.nih.gov/ij/, 1997-2004

38. Rheaume E., Lachance Y., Zhao H.F., Breton N., Dumont M., deLaunoit Y., Trudel C., Luu-The V., Simard J., Labrie F (1991). Structure and expression of a new complementary DNA encoding the almost exclusive 3 ß-hydroxysteroid dehydrogenase/ $\boldsymbol{\Delta}$ 5- $\boldsymbol{\Delta}$ 4-isomerase in human adrenals and gonads. Mol Endocrinol 5:1147-1157.

39. Ross M.H., Kaye G.I., Pawlina W. (2003). Histology A Text and Atlas with Cell and Molecular Biology. Lippincott Williams \&Wilkins, p.687.

40. Simpson E.R. (1979). Cholesterol side-chain cleavage, cytochrome P450, and the control of steroidogenesis. Mol Cell Endocrinol.,13: 213-27.

41. Shetty G., Krishnamurthy H., Krishnamurthy N.H., Bhatnagar S., Moudgal R.N (1997 Apr). Effect of estrogen deprivation on the reproductive physiology of male and female patients. J Steroid Biochem Mol Biol 63(3-6):157-66.

42. Simpson E.R., Mahendroo M.S., Means G.D. (1994). Aromatase cytochrome P450, the enzyme responsible for estrogen biosynthesis. Endocr Rev 15:342-55

43. 44.Simard J., Durocher F., Mebarki F., Turgeon C., Sanchez R., Labrie Y., Couet J., Trudel C., Rheaume E., Morel Y., Luu-The V., Labrie F (1996). Molecular biology and genetics of the 3 ß-hydroxysteroid dehydrogenase/ $\Delta 5-\Delta 4$ isomerase gene family. J Endocrinol 150(Suppl):S189-S207.

44. 45. Stocco D.M., Clarke B.J. (1994). Regulation of the acute production of steroids in steroidogenic cells. In Verhoeven G, Havenicht UF, editors. Molecular and Cellular Endocrinology of the Testis. Berlin: Springer Verlag, $367-98$.

45. 46. Strauss J.F 3rd, Martinez F., Kiriakidou M. (1996). Placental steroid hormone synthesis: unique features and unanswered questions.Biol Reprod., 54: 303-311.

46. 47. Thomas J.L., Myers R.P., Strickler RC ( 1989). Human placental 3 ß-hydroxy-5-ene-steroid dehydrogenase and steroid 5-4-ene-isomerase: purification from mitochondria and kinetic profiles, biophysical characterization of the purified mitochondrial and microsomal enzymes. J Steroid Biochem 33:209-217.

47. 48. Thomas J.L., Frieden C., Nash W.E., Strickler R.C. (1995). An NADH-induced conformational change that mediates the sequential $3 \beta$-hydroxysteroid dehydrogenase/isomerase activities is supported by affinity labeling and the time-dependent activation of isomerase. J Biol Chem 270:21003-21008.

48. 49. Thomas J.L., Duax W.L., Addlagatta A., Brandt S., Fuller R.R., Norris W (2003). Structure/function relationships responsible for coenzyme specificity and the isomerase activity of human type 13 3-hydroxysteroid dehydrogenase/isomerase. J Biol Chem 278:35483-35490.

49. 50. Uche-Nwachi E.O., Ezeokoli D., Adogwa A., Offiah V. (2001). Effect of Water Extract of Papaya Seed on the Germinal Epithelium of the Seminiferous Tubules of Sprague Dawley Rats. Acta Anat Nippon 76:517-521. 